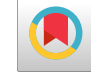

\title{
An Overview of Celiac Disease in Childhood Type 1 Diabetes
}

\author{
Iraj Shahramian, ${ }^{1}$ Ali Bazi, ${ }^{2, *}$ and Alireza Sargazi ${ }^{3}$ \\ ${ }^{1}$ Pediatric Ward, Amir - Al - Momenin Hospital, Zabol University of Medical Sciences, Zabol, Iran \\ ${ }^{2}$ Clinical Research Development Unit, Amir - Al - Momenin Hospital, Zabol University of Medical Sciences, Zabol, Iran \\ ${ }^{3}$ Student Research Committee, Zabol University of Medical Sciences, Zabol, Iran \\ "Corresponding author: Ali Bazi, Clinical Research Development Unit, Amir - Al - Momenin Hospital, Zabol University of Medical Sciences, Zabol, Iran. Tel/Fax: +98-5432232166, \\ E-mail: m.baziali@gmail.com
}

Received 2018 February 11; Revised 2018 June 09; Accepted 2018 June 13.

\begin{abstract}
Context: Celiac disease (CD) is a common phenomenon in children with Type 1 diabetes (T1D). In the present review, we have discussed the pathogenesis, diagnostic biomarkers, risk factors, and prognosis of CD in the context of pediatric T1D.

Evidence Acquisition: Literature published in Web of Science, PubMed, Scopus, Google Scholar, and Cochrane Library were scrutinized up to the end of 2017. The keywords of celiac disease, Type 1 diabetes, children, and pediatric were used in different combinations.

Results: Immune cytotoxic reactions along with dampen immune regulatory functions contribute to CD in the context of pediatric T1D. Many children with simultaneous CD and T1D do not represent with the clinical signs of the enteropathy rendering a diagnostic challenge. The most common screening tests in these children are routine serological tests of $C D$, anti - endomysial, anti - transglutaminase, and anti - deamidated gliadin peptide antibodies. Typing for human leukocyte antigens of DQ - 2 and DQ - 8 may assist in the diagnosis of silent CD in children with T1D. The most significant shared non - HLA genetic loci of CD and T1D comprise CTLA 4, TAGAP, IL - 18RAP, PTPN2, RGS1, SH2B3, CCR5. Interactions between these loci can be important in susceptibility to CD in T1D. Some new biomarkers have been suggested for diagnosis of CD including ischemia-modified albumin (IMA), soluble syndecan-1 (SSDC-1), regenerating gene I $\alpha$ (REG-I $\alpha$ ), Neurotensin, and Zonulin, which can be useful for diagnosis and screening of CD in childhood T1D. Conclusions: Overall, active seropositive CD seems to be of clinical importance in T1D with significant impacts on the quality of life and predisposition to diabetes associated complications. It is important to detect CD in the context of T1D to prevent potential risks contributing to morbidities and mortalities associated with either CD or T1D.
\end{abstract}

Keywords: Celiac Disease, Type 1 Diabetes, Human Leukocyte Antigen, Gluten

\section{Context}

Celiac disease $(C D)$, gluten - induced atrophy of the small intestine, is an autoimmune condition, which can be seen in the context of other autoimmune disorders including Type 1 diabetes (T1D). T1D may be diagnosed in association with $\mathrm{CD}$ as high as six times of healthy individuals. On the other hand, T1D patients may be seen with concurrent CD in $8 \%$ of cases (1). Children with T1D represent higher propensity to CD. Geographical distributions, consumption of gluten - containing regimes, ethnical origins, and environmental factors are among CD contributing factors in T1D patients. Here we have reviewed the pathogenesis, diagnostic biomarkers, risk factors, and prognosis of $\mathrm{CD}$ in the context of pediatric T1D.

\section{Evidence Acquisition}

Literature published in the Web of Science, PubMed, Scopus, Google Scholar, and Cochrane Library between
1990 up to the October 2017 where studied. The main keyword used were celiac disease, Type 1 diabetes, and pediatrics. The star; "*” truncation was applied as "C*eliac" to recruit the differentially spelled form; coeliac disease.

\section{Results}

\subsection{CD and T1D Juxtaposition, the Role of Immune System}

Gluten - induced auto - reactive antibodies and cell mediated cytotoxicity orchestrate the main pathological events in $C D(2)$. Of the all intraepithelial T lymphocytes (IELs) in patients with concurrent CD and T1D, nearly $12.5 \%$ have shown CD 25+, CD 39+, and Forkhead box P3 (FoxP3) + T regulatory phenotype $(3,4)$. Another characterized regulatory lymphocytic population in children with concurrent CD and T1D is CD3-/CD103+ cells, which further highlights the pivotal role of immunoregulation in the development of $\mathrm{CD}$ in the context of T1D (5). 
This higher regulatory function, however, seems to be functionally incompetent to prevent tissue damage in CD (4). Depressed local immunoregulatory function may be in part due to decreased activity of regulatory intestinal macrophages (CD163+). Some unspecific antibodies have been identified in patients with concurrent CD and T1D to represent binding specificity to these macrophages facilitating tissue damage by depleting these cells (Figure 1) (6). The role of immunomodulatory and inflammatory mediators in progress of $\mathrm{CD}$ in the context of T1D needs further evaluations.

\subsection{Clinical Features of CD in Children with T1D}

Isolated childhood CD presents with malnutrition and malabsorption, vitamin deficiencies, iron deficiency anemia, growth failure, short statue, diarrhea, anorexia, constipation, nausea, and abdominal distention. These clinical features can help in better identification of CD in the context of T1D. However, gastrointestinal symptoms could be very mild in T1D patients with $C D$, it can hinder the growth in affected children (7). Growth failure and malabsorption have been suggested as well representatives of possible CD in the context of pediatric $\mathrm{T} 1 \mathrm{D}(8)$. In those children who present none of the classic signs of $\mathrm{CD}$, the diagnosis is amenable using serological assessments.

\subsection{Screening of $C D$ in Children with $T 1 D$}

\subsubsection{Recommended Intervals}

Although routine screening for $\mathrm{CD}$ has been recommended in T1D, there is no consensus on the appropriate intervals for performing such tests. The American Diabetes Association and the International Society for Pediatric and Adolescent Diabetes recommended CD screening at the time of diabetes diagnosis $(9,10)$. In the follow up, however, the American Society has proposed performing screening tests whenever suggesting symptoms are evident. On the other hand, the International Society has suggested the screening program to be carried out annually for the first five years and biannually thereafter (10). The European and North American Societies for pediatric gastroenterology, hepatology, and nutrition have noted the ages of 2 and 3 years old, respectively, as the recommended time points in which the first CD screening tests should be performed in children with T1D $(11,12)$. For following up, however, the recent two societies have stated no specific requirements $(11,12)$.

\subsection{Screening Biomarkers}

There is a rough estimation by Australian Gastroenterology Society on the rate of undiagnosed CD ranging from $75 \%-83 \%$ (13). Currently, the screening tests fall into either serological evaluation, biopsy examination, and human leukocyte antigen (HLA) typing.

\subsection{Serological Markers of $C D$}

The most commonly used serological tests designed to detect gluten induced autoantibodies include anti gliadin (anti - GA), anti - endomysial (anti - EM), anti - transglutaminase (anti - tTG), and anti - deamidated gliadin peptide (anti - DGP) antibodies (1). The most sensitive and specific serological tests for CD include IgA antibodies against either tTG or EMA, and both IgA and IgG antibodies for DGP (14). It seems that detection of IgG isotypes of anti - tTG or anti - DGP does not augment sensitivity for CD diagnosis in the conditions with high titer IgA isotypes (15). Overall, serologic tests are useful to exclude CD in children with T1D with a negative predictive value of $98 \%$ (16).

Anti - tTG antibody is the most commonly ordered test for screening CD recommended by American, European, British, and North American societies for both diagnosis and follow up purposes (10-12,17). Anti - tTG rendered a 90\% positive predictive value, which was correlated with the antibody titer with higher titers correlating with higher predictive values $(15,18)$. In addition, Elitsur et al., noted that anti - tTG antibody titer is three times higher than upper limits is not a good representative of CD in children (19). Anti - tTG antibodies have been reported in a close relationship with HLA-DQB1*02 (20) and HLA - DQ2.5 (21).

IgA anti - EM antibodies are also highly specific for diagnosis of CD associated with childhood T1D (22). IgG1 isotypes of anti - EMA have been strongly associated with biopsy diagnosed CD in T1D (23). These antibodies may also be used as predicting factors for future CD development (24). On the other hand, anti - GA antibodies can be useful for diagnosis of late - onset CD in high risk populations (24). Some new serological markers have been proposed such as antibodies against serum albumin (25) and reticulin (26), which may be useful in screening the progression of $\mathrm{CD}$ in at risk populations.

\subsection{Intestinal Biopsy Examination}

Diabetic children with positive CD serology may demonstrate different histopathological features as compared with their non - diabetic counterparts. Intestinal histological changes in children with concurrent CD and T1D showed erythematous alternations resembling reflux esophagitis, which was different from the pattern seen in isolated CD (27). Intestinal biopsy, as the gold standard, could assist in CD diagnosis in asymptomatic cases.

\subsection{HLA Typing}

HLA - DQ2 has been mapped in 95\% of patients with CD $(28,29)$, while HLA - DQ8 is seen in the remained 5\% (30). HLA-DQ inheritance has been observed in one - third of patients with T1D (28). Accordingly, HLADQ2 comprised the most common allele identified in children with co - existence of CD and T1D (31). In fact, the inheritance of HLA $\mathrm{DQ}$ is one of the main predisposing factor for development 


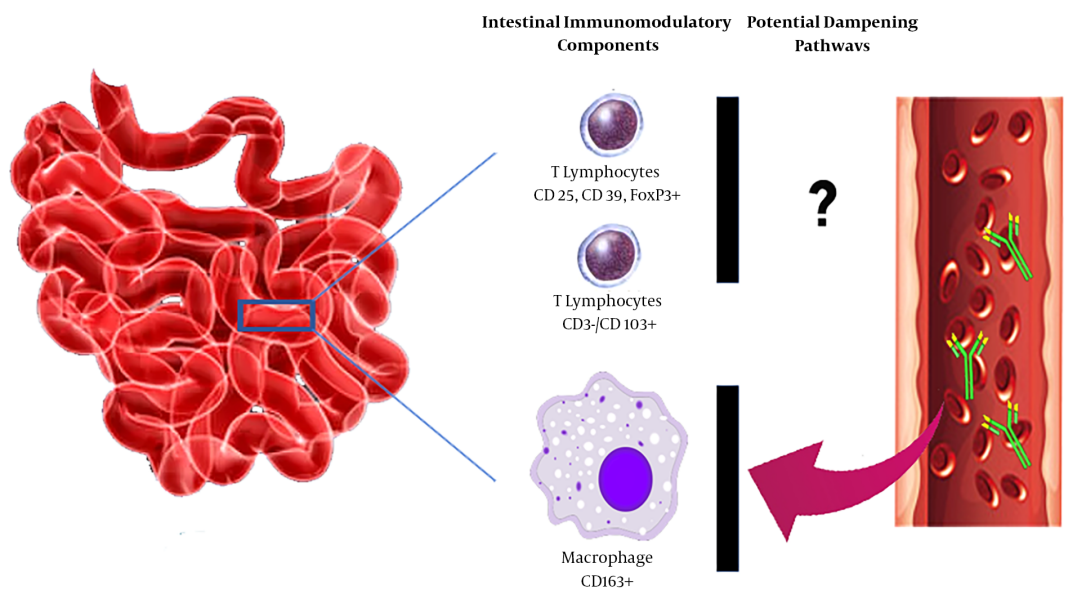

Figure 1. Potential intestinal immunomodulatory components executed in patients with T1D and CD. Suppression of CD163+ macrophages by high - affinity auto - reactive antibodies can suppress activity of these cells. Incompetent immunoregulation can result in higher level intestinal mucosa damage in patients with concurrent T1D and CD. Abbreviations; T1D; type 1 diabetes, CD; celiac disease.

of CD in childhood T1D (32). The most significant association between HLA haplotypes and concurrent CD and T1D has been noted for HLA - DR3 - DQ2 and DR4 - DQ8 combinations, as well as presence of DQB1*06:02 allele (33). The role of HLA molecules, also known as Class II major histocompatibility complex (MHCII)-falls into their gliadin - derived antigens presenting activity to CD4+ lymphocytes $(34,35)$.

HLA typing has been recommended as the screening test for CD in high risk children by the British (17) and European (11) societies for pediatric gastroenterology, hepatology, and nutrition. Screening for HLA - DQ2/DQ8 alleles is recommended as a reliable negative predictor of $C D$ in individuals with suggesting symptoms, as well as at risk populations such as T1D $(36,37)$. Despite these notions, using HLA - DQ2/DQ8 typing as a routine screening test is hindered owing to their high penetrance in general population, which limits their positive predictive values (38). Furthermore, applicability of this approach for screening CD in populations with low penetrance of these alleles is not recommended as results in high rate of undiagnosed cases (39).

\subsection{Non - HLA Genetic Risk Factors of CD in T1D}

According to a Genome - wide association study (GWAS), CD susceptibility is modified by at least 70 potential genes mapped within 42 non - HLA loci (40). Seven shared genetic loci between CD and T1D have been addressed by Smyth et al., (41). The list of shared genetic loci between CD and T1D are likely to be increased by more comprehensive studies. Some other genetic polymorphisms that have been associated with an elevated risk of CD in the context of T1D include rs10754558 and rs358294199 SNPs of
NLRP3 (42), polymorphisms in IL - $6(43,44)$, CD14 $(45,46)$, and IL12A/SCHIP, CCR1, CCR2, CCr3, LPP, IL-17 (44, 47-49).

3.9. New Potential Biomarkers for Diagnosis and Screening CD Some new potential markers for diagnosis of CD include Ischemia - modified albumin (IMA), Soluble Syndecan - 1 (SSDC1), Regenerating gene I $\alpha$ (REGI $\alpha$ ), Neurotensin (NT), Zonulin, and n - 3 polyunsaturated fatty acids ( $\mathrm{n}-3$ PUFA). IMA is a metal - binding modified albumin and a marker of oxidative stress. Clinical significance of elevated levels of IMA has been evaluated in some disorders such as ischemic heart disorders, thalassemia, renal failure, and diabetes (50-52). SDC1 roles as a mediator derived from intestinal mucosa glycocalyx involved in maintaining permeability of intestinal epithelium. The role of SDC1 in regulating intestinal permeability makes it a potential marker with a central role in pathogenesis of CD (53-55). REGI $\alpha$ is a molecule with a substantial role in tissue remodeling processes that its levels have been high in active CD (56, 57). NT is an intestinal hormone synthesized and released by specialized cells located mainly in jejunum and ileum of small intestine (58). NT can promote inflammatory responses through inducing nuclear factor kappa $\mathrm{B}(\mathrm{NF}-\kappa \mathrm{B})$ signaling pathway and production of proinflammatory cytokines $(59,60)$. Zonulin is another mediator directly involved in regulation of intestinal permeability by dissociating tight junction complexes (61-63). Belonging to $n-3$ long - chain polyunsaturated fatty acids ( $\mathrm{n}-3$ LCPUFA) family, $\mathrm{n}$ - 3 PUFA and its abnormal abdominal absorption in $\mathrm{CD}$ could pave the route for recruiting the molecule as a diagnostic marker in this condition (64). Table 1 has summarized studies assessing diagnostic applicability of these markers. 


\begin{tabular}{|c|c|c|c|c|}
\hline Biomarkers & Authors, Year & Population & Implications & Ref \\
\hline \multirow[t]{2}{*}{ IMA } & Yuksel et al., 2017 & $\begin{array}{l}65 \text { patients with } \mathrm{CD} \text { and } 65 \text { healthy } \\
\text { control }\end{array}$ & $\begin{array}{l}\text { IMA levels were higher in celiac patients respective to controls. Among CD } \\
\text { patients, those with positive serological test had significantly higher IMA } \\
\text { levels }\end{array}$ & (54) \\
\hline & Sayar et al, 2015 & $\begin{array}{l}37 \text { children with } \mathrm{CD} \text { and } 29 \text { healthy } \\
\text { controls }\end{array}$ & $\begin{array}{l}\text { IMA levels were significantly higher in patients. IMA level showed } \\
\text { moderately positive correlation with t-TGA and Marsh Score. The level of } \\
\text { IMA dropped significantly following a GFD. }\end{array}$ & (55) \\
\hline SD - 1 & $\begin{array}{l}\text { Yablecovitch et al., } \\
2017\end{array}$ & $\begin{array}{l}49 \text { children with } \mathrm{CD} \text { and no history of } \\
\text { treatment, } 15 \text { children with } \\
\text { abdominal pain and no evidences of } \\
\text { CD }\end{array}$ & $\begin{array}{l}\text { The levels of soluble SD - } 1 \text { were significantly higher in CD children at the } \\
\text { time of diagnosis compared to controls. The levels were significantly } \\
\text { correlated with the degree of villous inflammation }\end{array}$ & (53) \\
\hline REGIa & Planas et al., 2011 & $\begin{array}{l}40 \text { patients with } \mathrm{CD}, 35 \text { healthy } \\
\text { controls }\end{array}$ & $\begin{array}{l}\text { REGIa showed significantly elevated levels compared to control subjects. } \\
\text { The levels decreased following GFD which was correlated with reduction in } \\
\text { tTG antibodies. I comparison, those patients with T1D showed normal } \\
\text { levels of REG Ia. }\end{array}$ & (57) \\
\hline Zonulin & $\begin{array}{l}\text { Vorobjova et al., } \\
2017\end{array}$ & $\begin{array}{l}40 \text { subjects with } \mathrm{CD} \text {, and } 40 \\
\text { individuals with small intestine } \\
\text { functional syplasia as control }\end{array}$ & $\begin{array}{l}\text { Serum zonulin levels were significantly higher in } \mathrm{CD} \text { patients and were } \\
\text { associated with Marsh score III. This correlation was prominent in CD } \\
\text { patients with concurrent T1D. }\end{array}$ & (63) \\
\hline Pro NT & Monten et al., 2016 & $\begin{array}{l}96 \text { children with } \mathrm{CD} \text { and } 89 \text { healthy } \\
\text { controls }\end{array}$ & $\begin{array}{l}\text { The plasma level of pro - NT was higher in CD compared to non - diseased } \\
\text { cases. The levels were correlated with intestinal damage degree, and anti - } \\
\text { tTG antibodies }\end{array}$ & (60) \\
\hline $\begin{array}{l}\text { n - 3 } \\
\text { PUFA }\end{array}$ & Tarnok et al., 2015 & $\begin{array}{l}20 \text { children with } C D, 8 \text { children with } \\
\text { coexistence of } C D \text { and } T 1 D \text {, and } 21 \\
\text { healthy children }\end{array}$ & $\begin{array}{l}\text { The plasma levels of docosapentaenoic, docosahexaenoic, } n-3 \text { PUFA, and } \\
\text { long chains ( } \mathrm{n}-3 \text { LCPUFA) were significantly lower in CD+T1D group } \\
\text { compared to CD alone or controls. }\end{array}$ & (64) \\
\hline
\end{tabular}

Abbreviations: CD, Celiac disease; IMA, Ischemia - modified albumin; NT, Neurotensin; PUFA, n - 3 polyunsaturated fatty acidsn - 3; REGIa, regenerating gene I alpha; SD 1 , Solouble Syndecan - 1 .

\subsection{Prognostic Impacts of CD on Childhood T1D}

Abnormal lipid profile such as decreased HDL - C and elevated LDL - $C$ in patients with concurrent CD and T1D has been noted, which may contribute to the higher risk of cardiovascular incidents in these patients (65). CD can also exaggerate complications such as nephropathy, retinopathy, as well as other auto immune disorders in children with T1D (37). CD may contribute to lower bone density, renal insufficiency, and quality of life of affected children and adults with T1D (66-68). Both Vitamin D deficiency (69) and antibodies against bone regulatory hormone - osteoprotegerin - participate in lower than optimal bone density in patients with $\mathrm{CD}(70)$. CD may also increase the risk of gastrointestinal tumors (71).

On the other hand, neither nutritional status, nor life quality of children with concurrent $C D$ and T1D were different compared to individuals with T1D alone (72). In another study, patients with T1D who developed CD revealed no increase in complication rate in comparison to their counterparts without $\operatorname{CD}(73,74)$. Accordingly, diagnosis of CD in the context of T1D showed no significant impact on HbA1c levels in another study (75). However, Leeds et al., argued that children with T1D associated with active CD or high levels of anti - tTG antibodies have a higher risk for diabetes associated complications (76). In general, timely diagnosis and management of CD in the context of T1D could protect patients from reduction in bone density and anemia, as well as deterioration in gastrointestinal functions, and provide them with a better quality of life.

\section{Conclusions}

Immune cytotoxic reactions with dampen immune regulatory functions can contribute to $\mathrm{CD}$ pathogenies in the context of T1D. The most common screening tests for CD include anti - GA, anti - EM, anti - tTG, and anti - DG antibodies. Typing for HLA of DQ - 2 and DQ - 8 can assist in diagnosis of silent CD in children with T1D. Newly proposed biomarkers of CD including IMA, SSDC1, REG I $\alpha$, pro - NT, Zonulin, and n - 3 PUFA can be used for diagnosis and screening CD in childhood T1D. Overall, active seropositive CD seems to be of clinical importance in T1D with significant impacts on the quality of life of the patients and occurrence of diabetes associated complications. Adherence to GFD is recommended in T1D children with active or silent $\mathrm{CD}$ to ameliorate related complications.

\section{Footnote}

Conflict of Interests: Authors have no conflict of interest.

\section{References}

1. Shahramian I, Dehghani SM, Haghighat M, Noori NM, Teimouri AR, Sharafi E, et al. Serologic evaluation of celiac disease in patients with beta thalassemia major and control. Gastroenterol Hepatol Bed Bench. 2015;8(2):153-9. [PubMed: 25926941]. [PubMed Central: PMC4403028]

2. Kivling A, Nilsson L, Falth-Magnusson K, Sollvander S, Johanson C, Faresjo M. Diverse foxp3 expression in children with type 1 diabetes and celiac disease. Ann N Y Acad Sci. 2008;1150:273-7. doi: 10.1196/annals.1447.018. [PubMed: 19120312]. 
3. Cook L, Munier CML, Seddiki N, van Bockel D, Ontiveros N, Hardy MY, et al. Circulating gluten-specific FOXP3(+)CD39(+) regulatory $\mathrm{T}$ cells have impaired suppressive function in patients with celiac disease. J Allergy Clin Immunol. 2017;140(6):1592-1603 e8. doi: 10.1016/j.jaci.2017.02.015. [PubMed: 28283419].

4. Uibo R, Panarina M, Teesalu K, Talja I, Sepp E, Utt M, et al. Celiac disease in patients with type 1 diabetes: a condition with distinct changes in intestinal immunity? Cell Mol Immunol. 2011;8(2):1506. doi: 10.1038/cmi.2010.66. [PubMed: 21317917]. [PubMed Central: PMC4003136].

5. Valle J, Morgado JMT, Ruiz-Martin J, Guardiola A, Lopes-Nogueras M, Garcia-Vela A, et al. Flow cytometry of duodenal intraepithelial lymphocytes improves diagnosis of celiac disease in difficult cases. United European Gastroenterol J. 2017;5(6):819-26. doi: 10.1177/2050640616682181. [PubMed: 29026596]. [PubMed Central: PMC5625870].

6. Sonier B, Strom A, Wang GS, Patrick C, Crookshank JA, Mojibian M, et al. Antibodies from a patient with type 1 diabetes and celiac disease bind to macrophages that express the scavenger receptor CD163. Can J Gastroenterol.2011;25(6):327-9. [PubMed: 21766094]. [PubMed Central: PMC3142606].

7. Cohn A, Sofia AM, Kupfer SS. Type 1 diabetes and celiac disease: clinical overlap and new insights into disease pathogenesis. Curr Diab Rep. 2014;14(8):517. doi: 10.1007/s11892-014-0517-x. [PubMed: 24952108]. [PubMed Central: PMC4156157].

8. Holmes GK. Screening for coeliac disease in type 1 diabetes. Arch Dis Child. 2002;87(6):495-8. [PubMed: 12456547]. [PubMed Central: PMC1755832].

9. American Diabetes Association . 12. Children and Adolescents: Standards of Medical Care in Diabetes-2018. Diabetes Care. 2018;41(Suppl 1):S126-36. doi: 10.2337/dc18-S012. [PubMed: 29222383].

10. Couper JJ, Haller MJ, Ziegler AG, Knip M, Ludvigsson J, Craig ME, et al. ISPAD Clinical Practice Consensus Guidelines 2014. Phases of type 1 diabetes in children and adolescents. Pediatr Diabetes. 2014;15 Suppl 20:18-25. [PubMed: 25325095].

11. Husby S, Koletzko S, Korponay-Szabo IR, Mearin ML, Phillips A, Shamir R, et al. European Society for Pediatric Gastroenterology, Hepatology, and Nutrition guidelines for the diagnosis of coeliac disease. J Pediatr Gastroenterol Nutr. 2012;54(1):136-60. doi: 10.1097/MPG.0b013e31821a23do. [PubMed: 22197856].

12. Hill ID, Dirks MH, Liptak GS, Colletti RB, Fasano A, Guandalini S, et al. Guideline for the diagnosis and treatment of celiac disease in children: recommendations of the North American Society for Pediatric Gastroenterology, Hepatology and Nutrition. J Pediatr Gastroenterol Nutr. 2005;40(1):1-19. [PubMed: 15625418].

13. Rubio-Tapia A, Ludvigsson JF, Brantner TL, Murray JA, Everhart JE. The prevalence of celiac disease in the United States. Am J Gastroenterol. 2012;107(10):1538-44. quiz 1537, 1545. doi: 10.1038/ajg.2012.219. [PubMed: 22850429].

14. Waisbourd-Zinman O, Hojsak I, Rosenbach Y, Mozer-Glassberg Y, Shalitin S, Phillip M, et al. Spontaneous normalization of anti-tissue transglutaminase antibody levels is common in children with type 1 diabetes mellitus. Dig Dis Sci. 2012;57(5):1314-20. doi: 10.1007/s10620-0112016-0. [PubMed: 22173747].

15. Ermarth A, Bryce M, Woodward S, Stoddard G, Book L, Jensen MK. Identification of Pediatric Patients With Celiac Disease Based on Serology and a Classification and Regression Tree Analysis. Clin Gastroenterol Hepatol. 2017;15(3):396-402 e2. doi: 10.1016/j.cgh.2016.10.035. [PubMed: 27847281]. [PubMed Central: PMC5316297].

16. Bannister EG, Cameron DJ, Ng J, Chow CW, Oliver MR, Alex G, et al. Can celiac serology alone be used as a marker of duodenal mucosal recovery in children with celiac disease on a gluten-free diet? Am J Gastroenterol. 2014;109(9):1478-83. doi: 10.1038/ajg.2014.200. [PubMed: 25070050].

17. Murch S, Jenkins H, Auth M, Bremner R, Butt A, France S, et al. Joint BSPGHAN and Coeliac UK guidelines for the diagnosis and management of coeliac disease in children. Arch Dis Child. 2013;98(10):806-11. doi: 10.1136/archdischild-2013-303996. [PubMed: 23986560].

18. Jora R, Raghuvanshi V, Payal V, Sharma P, Vishnoi SK. Correlation of Tissue Transglutaminase with Modified Marsh Grading in Celiac Disease: A Prospective Cohort Study. Indian J Pediatr. 2017;84(7):515-20. doi: 10.1007/s12098-017-2323-3. [PubMed: 28321610].

19. Elitsur Y, Sigman T, Watkins R, Porto AF, Leonard Puppa EL, Foglio EJ, et al. Tissue Transglutaminase Levels Are Not Sufficient to Diagnose Celiac Disease in North American Practices Without Intestinal Biopsies. Dig Dis Sci. 2017;62(1):175-9. doi: 10.1007/s10620-016-4354-4. [PubMed: 27778203].

20. Agardh D, Nilsson A, Tuomi T, Lindberg B, Carlsson AK, Lernmark A, et al. Prediction of silent celiac disease at diagnosis of childhood type 1 diabetes by tissue transglutaminase autoantibodies and HLA. Pediatr Diabetes. 2001;2(2):58-65. doi: 10.1034/j.1399-5448.2001.002002058.x. [PubMed: 15016199].

21. Arregui MV, Urmeneta JM, Brito HL, De Esteban JP, Martinez CP, Llenas LF, et al. The role of flow cytometry in celiac disease screening using human leukocyte antigen in adult patients with type 1 diabetes mellitus. Ann Gastroenterol.2017;30(2):179-85. doi:10.20524/aog.2016.0113. [PubMed: 28243038]. [PubMed Central: PMC5320030].

22. Dretzke J, Cummins C, Sandercock J, Fry-Smith A, Barrett T, Burls A. Autoantibody testing in children with newly diagnosed type 1 diabetes mellitus. Health Technol Assess. 2004;8(22):iii-xi. 1-183. [PubMed: 15191683].

23. Picarelli A, Sabbatella L, Di Tola M, Vetrano S, Casale C, Anania MC, et al. Anti-endomysial antibody of IgG1 isotype detection strongly increases the prevalence of coeliac disease in patients affected by type I diabetes mellitus. Clin Exp Immunol. 2005;142(1):111-5. doi: 10.1111/j.1365-2249.2005.02866.x. [PubMed: 16178863]. [PubMed Central: PMC1809494].

24. Grodzinsky E, Falth-Magnusson K, Hogberg L, Jansson G, Laurin $\mathrm{P}$, Stenhammar L. IgA endomysium antibodies-an early predictor for celiac disease in children without villous atrophy. Acta Paediatr. 2008;97(7):972-6. doi: 10.1111/j.1651-2227.2008.00881.x. [PubMed: 18489624].

25. Rodriguez-Juan C, Sala-Silveira L, Perez-Blas M, Valeri AP, Aguilera N, Lopez-Santalla M, et al. Increased levels of bovine serum albumin antibodies in patients with type 1 diabetes and celiac disease-related antibodies. J Pediatr Gastroenterol Nutr. 2003;37(2):132-5. [PubMed: 12883297].

26. Maki M, Huupponen T, Holm K, Hallstrom O. Seroconversion of reticulin autoantibodies predicts coeliac disease in insulin dependent diabetes mellitus. Gut. 1995;36(2):239-42. [PubMed: 7883223]. [PubMed Central: PMC1382410].

27. Tanpowpong P, Broder-Fingert S, Katz AJ, Camargo CJ. Features of children with positive celiac serology and type 1 diabetes mellitus. Pediatr Int. 2015;57(5):1028-30. doi: 10.1111/ped.12766. [PubMed: 26508189].

28. Ludvigsson JF, Ludvigsson J, Ekbom A, Montgomery SM. Celiac disease and risk of subsequent type 1 diabetes: a general population cohort study of children and adolescents. Diabetes Care. 2006;29(11):2483-8. doi: 10.2337/dc06-0794. [PubMed: 17065689].

29. Tye-Din JA, Cameron DJ, Daveson AJ, Day AS, Dellsperger P, Hogan $C$, et al. Appropriate clinical use of human leukocyte antigen typing for coeliac disease: an Australasian perspective. Intern Med J. 2015;45(4):441-50. doi: 10.1111/imj.12716. [PubMed: 25827511]. [PubMed Central: PMC4405087]

30. Kaur A, Shimoni O, Wallach M. Celiac disease: from etiological factors to evolving diagnostic approaches. J Gastroenterol. 2017;52(9):1001-12. doi: 10.1007/s00535-017-1357-7. [PubMed: 28631048].

31. Ciacci C, Zingone F. Dietary gluten and the development of celiac disease and type 1 diabetes. Nutr Diet Suppl. 2016;8:51-6. doi: $10.2147 /$ nds.s74713.

32. Adlercreutz EH, Svensson J, Hansen D, Buschard K, Lernmark A, Mortensen HB, et al. Prevalence of celiac disease autoimmunity in children with type 1 diabetes: regional variations across the Oresund strait between Denmark and southernmost Sweden. Pediatr Diabetes. 2015;16(7):504-9. doi: 10.1111/pedi.12200. [PubMed: 25131687].

33. Lernmark A. Environmental factors in the etiology of type 1 diabetes, celiac disease, and narcolepsy. Pediatr Diabetes. 2016;17 Suppl 22:65-72. doi: 10.1111/pedi.12390. [PubMed: 27411439]. [PubMed Central: PMC5473290].

34. Liu E, McDaniel K, Case S, Yu L, Gerhartz B, Ostermann N, et al. Exploring $\mathrm{T}$ cell reactivity to gliadin in young children with newly diagnosed celiac disease. Autoimmune Dis. 2014;2014:927190. 
doi: 10.1155/2014/927190. [PubMed: 24724018]. [PubMed Central: PMC3958769].

35. Lundin KE, Scott H, Hansen T, Paulsen G, Halstensen TS, Fausa O, et al. Gliadin-specific, HLA-DQ(alpha $1^{*} 0501$,beta $1^{*} 0201$ ) restricted T cells isolated from the small intestinal mucosa of celiac disease patients. J Exp Med. 1993;178(1):187-96. [PubMed: 8315377]. [PubMed Central: PMC2191064].

36. Diaz-Redondo A, Miranda-Bautista J, Garcia-Lledo J, Gisbert JP, Menchen L. The potential usefulness of human leukocyte antigen typing for celiac disease screening: A systematic review and metaanalysis. Rev Esp Enferm Dig. 2015;107(7):423-9. [PubMed: 26140635].

37. Weiss B, Pinhas-Hamiel O. Celiac Disease and Diabetes: When to Test and Treat. J Pediatr Gastroenterol Nutr. 2017;64(2):175-9. doi: 10.1097/MPG.0000000000001388. [PubMed: 27574884].

38. Hadithi M, von Blomberg BM, Crusius JB, Bloemena E, Kostense PI, Meijer JW, et al. Accuracy of serologic tests and HLA-DQ typing for diagnosing celiac disease. Ann Intern Med. 2007;147(5):294-302. [PubMed: 17785484].

39. Fukunaga $M$, Ishimura $N$, Fukuyama $C$, Izumi D, Ishikawa $N$, Araki A, et al. Celiac disease in non-clinical populations of Japan.J Gastroenterol. 2018;53(2):208-14. doi:10.1007/s00535-017-1339-9. [PubMed: 28389733]

40. Dubois PC, Trynka G, Franke L, Hunt KA, Romanos J, Curtotti A, et al. Multiple common variants for celiac disease influencing immune gene expression. Nat Genet. 2010;42(4):295-302. doi: 10.1038/ng.543. [PubMed: 20190752]. [PubMed Central: PMC2847618].

41. Smyth DJ, Plagnol V, Walker NM, Cooper JD, Downes K, Yang JH, et al. Shared and distinct genetic variants in type 1 diabetes and celiac disease. N Engl J Med. 2008;359(26):2767-77. doi: 10.1056/NEJMoa0807917. [PubMed: 19073967]. [PubMed Central: PMC2840835].

42. Pontillo A, Brandao L, Guimaraes R, Segat L, Araujo J, Crovella S. Two SNPs in NLRP3 gene are involved in the predisposition to type-1 diabetes and celiac disease in a pediatric population from northeast Brazil. Autoimmunity. 2010;43(8):583-9. doi: 10.3109/08916930903540432. [PubMed: 20370570].

43. Mysliwiec M, Mysliwska J, Zorena K, Balcerska A, Malinowska E, Wisniewski P. Interleukin $6-174(\mathrm{G}>\mathrm{C})$ gene polymorphism is related to celiac disease and autoimmune thyroiditis coincidence in diabetes type 1 children. Diabetes Res Clin Pract. 2008;82(1):108-12. doi: 10.1016/j.diabres.2008.07.004. [PubMed: 18692934].

44. Akbulut UE, Cebi AH, Sag E, Ikbal M, Cakir M. Interleukin-6 and interleukin-17 gene polymorphism association with celiac disease in children. Turk J Gastroenterol. 2017;28(6):471-5. doi: 10.5152/tig.2017.17092. [PubMed: 28928101].

45. Dezsofi A, Szebeni B, Hermann CS, Kapitany A, Veres G, Sipka S, et al. Frequencies of genetic polymorphisms of TLR4 and CD14 and of HLA-DQ genotypes in children with celiac disease, type 1 diabetes mellitus, or both. J Pediatr Gastroenterol Nutr. 2008;47(3):283-7. doi: 10.1097/MPG.0b013e31816de885. [PubMed: 18728522].

46. Catamo E, Segat L, Lenarduzzi S, Petix V, Morgutti M, Crovella S. CD14 polymorphisms correlate with an augmented risk for celiac disease in Italian patients. Genes Immun. 2012;13(6):489-95. doi: 10.1038/gene.2012.23. [PubMed: 22648004].

47. Amundsen SS, Rundberg J, Adamovic S, Gudjonsdottir AH, Ascher H, Ek J, et al. Four novel coeliac disease regions replicated in an association study of a Swedish-Norwegian family cohort. Genes Immun. 2010;11(1):79-86. doi: 10.1038/gene.2009.67. [PubMed: 19693089].

48. Romanos J, Barisani D, Trynka G, Zhernakova A, Bardella MT, Wijmenga C. Six new coeliac disease loci replicated in an Italian population confirm association with coeliac disease. J Med Genet. 2009;46(1):60-3. doi: 10.1136/jmg.2008.061457. [PubMed: 18805825].

49. Guo CC, Wang M, Cao FD, Huang WH, Xiao D, Ye XG, et al. Meta-Analysis on Associations of RGS1 and IL12A Polymorphisms with Celiac Disease Risk. Int J Mol Sci. 2016;17(4):457. doi: 10.3390/ijms17040457. [PubMed: 27043536]. [PubMed Central: PMC4848913].

50. Sbarouni E, Georgiadou P, Voudris V. Ischemia modified albumin changes - review and clinical implications. Clin Chem Lab Med. 2011;49(2):177-84. doi: 10.1515/CCLM.2011.037. [PubMed: 21083441].

51. Cichota LC, Moresco RN, Duarte MM, da Silva JE. Evaluation of ischemia-modified albumin in anemia associated to chronic kidney disease. J Clin Lab Anal. 2008;22(1):1-5. doi: 10.1002/jcla.20226. [PubMed: 18200583].
52. Awadallah SM, Atoum MF, Nimer NA, Saleh SA. Ischemia modified albumin: an oxidative stress marker in beta-thalassemia major Clin Chim Acta. 2012;413(9-10):907-10. doi: 10.1016/j.cca.2012.01.037. [PubMed: 22336636].

53. Yablecovitch D, Oren A, Ben-Horin S, Fudim E, Eliakim R, Saker T, et al. Soluble Syndecan-1: A Novel Biomarker of Small Bowel Mucosal Damage in Children with Celiac Disease. Dig Dis Sci. 2017;62(3):755-60. doi 10.1007/s10620-016-4415-8. [PubMed: 28025744].

54. Yuksel M, Kaplan M, Ates I, Ozin YO, Kilic H, Kuzu UB, et al. The relation between ischemia modified albumin level and autoimmunity/chronic inflammation in celiac disease. Turkish J Biochem. 2017;42(3). doi: 10.1515/tjb-2016-0296.

55. Sayar E, Ozdem S, Uzun G, Islek A, Yilmaz A, Artan R. Total oxidant status, total antioxidant capacity and ischemia modified albumin levels in children with celiac disease. Turk J Pediatr. 2015;57(5):498-503. [PubMed: 27411418].

56. Brusca I. Overview of Biomarkers for Diagnosis and Monitoring of Celiac Disease. Adv Clin Chem. 2015;68:1-55. doi: 10.1016/bs.acc.2014.12.006.

57. Planas R, Pujol-Autonell I, Ruiz E, Montraveta M, Cabre E, LucasMartin A, et al. Regenerating gene Ialpha is a biomarker for diagnosis and monitoring of celiac disease: a preliminary study. Transl Res. 2011;158(3):140-5. doi: 10.1016/j.trsl.2011.04.004. [PubMed: 21867979].

58. Egerod KL, Engelstoft MS, Grunddal KV, Nohr MK, Secher A, Sakata I, et al. A major lineage of enteroendocrine cells coexpress CCK, secretin, GIP, GLP-1, PYY, and neurotensin but not somatostatin. Endocrinology. 2012;153(12):5782-95. doi: 10.1210/en.2012-1595. [PubMed: 23064014].

59. Zhao D, Pothoulakis C. Effects of NT on gastrointestinal motility and secretion, and role in intestinal inflammation. Peptides. 2006;27(10):2434-44. doi: 10.1016/j.peptides.2005.12.016. [PubMed: 16872719].

60. Monten C, Torinsson Naluai A, Agardh D. Role of proneurotensin as marker of paediatric coeliac disease. Clin Exp Immunol. 2016;186(3):387-92. doi: 10.1111/cei.12864. [PubMed: 27612962] [PubMed Central: PMC5108069].

61. Fasano A. Zonulin and its regulation of intestinal barrier function the biological door to inflammation, autoimmunity, and cancer. Physiol Rev. 2011;91(1):151-75. doi: 10.1152/physrev.00003.2008. [PubMed: 21248165].

62. Fasano A. Zonulin, regulation of tight junctions, and autoimmune diseases. Ann N Y Acad Sci. 2012;1258:25-33. doi 10.1111/j.1749-6632.2012.06538.x. [PubMed: 22731712]. [PubMed Central: PMC3384703].

63. Vorobjova T, Raikkerus H, Kadaja L, Talja I, Uibo O, Heilman K, et al. Circulating Zonulin Correlates with Density of Enteroviruses and Tolerogenic Dendritic Cells in the Small Bowel Mucosa of Celiac Disease Patients. Dig Dis Sci. 2017;62(2):358-71. doi: 10.1007/s10620-016-4403-z. [PubMed: 27995404].

64. Tarnok A, Marosvolgyi T, Szabo E, Gyorei E, Decsi T. Low n-3 long-chain polyunsaturated fatty acids in newly diagnosed celiac disease in children with preexisting type 1 diabetes mellitus. J Pediatr Gastroenterol Nutr. 2015;60(2):255-8. doi: 10.1097/MPG.0000000000000561. [PubMed: 25207475].

65. Salardi S, Maltoni G, Zucchini S, Iafusco D, Zanfardino A, Confetto S, et al. Whole lipid profile and not only HDL cholesterol is impaired in children with coexisting type 1 diabetes and untreated celiac disease. Acta Diabetol. 2017;54(10):889-94. doi: 10.1007/s00592-017-1019-5. [PubMed: 28639064].

66. Simmons KM, McFann K, Taki I, Liu E, Klingensmith G], Rewers M], et al. Reduced Bone Mineral Density Is Associated with Celiac Disease Autoimmunity in Children with Type 1 Diabetes. J Pediatr. 2016;169:44-8 e1. doi: 10.1016/j.jpeds.2015.10.024. [PubMed: 26561381]. [PubMed Central: PMC4849876].

67. Bakker SF, Tushuizen ME, von Blomberg BM, Bontkes HJ, Mulder CJ, Simsek S. Screening for coeliac disease in adult patients with type 1 diabetes mellitus: myths, facts and controversy. Diabetol Metab Syndr. 2016;8:51. doi: 10.1186/s13098-016-0166-0. [PubMed: 27478507] [PubMed Central: PMC4966870].

68. Mollazadegan K, Fored M, Lundberg S, Ludvigsson J, Ekbom A, Montgomery SM, et al. Risk of renal disease in patients with both type 
1 diabetes and coeliac disease. Diabetologia. 2014;57(7):1339-45. doi: 10.1007/s00125-014-3223-y. [PubMed: 24663809].

69. Topal E, Catal F, Yildirim Acar N, Ermistekin H, Sinanoglu MS, Karabiber $\mathrm{H}$, et al. Vitamin and mineral deficiency in children newly diagnosed with celiac disease. Turkish J Med Sci. 2015;45:833-6. doi: 10.3906/sag-1408-94.

70. Real A, Gilbert N, Hauser B, Kennedy N, Shand A, Gillett H, et al. Characterisation of osteoprotegerin autoantibodies in coeliac disease. Calcif Tissue Int. 2015;97(2):125-33. doi: 10.1007/s00223-015-0023-4. [PubMed: 26092508].

71. Naderi M, Shahramian I, Delaramnasab M, Bazi A. Coincidence of celiac disease with nongastrointestinal tumors in children. Pediatr Hematol Oncol. 2017;34(8):478-82. doi: 10.1080/08880018.2017.1404171. [PubMed: 29219666].

72. Nunes-Silva JG, Nunes VS, Schwartz RP, Mlss Trecco S, Evazian D, Correa-Giannella ML, et al. Impact of type 1 diabetes mellitus and celiac disease on nutrition and quality of life. Nutr Diabetes. 2017;7(1). e239. doi: 10.1038/nutd.2016.43. [PubMed: 28067892]. [PubMed Central: PMC5301040].

73. Pham-Short A, Donaghue KC, Ambler G, Chan AK, Hing S, Cusumano
J, et al. Early elevation of albumin excretion rate is associated with poor gluten-free diet adherence in young people with coeliac disease and diabetes. Diabet Med. 2014;31(2):208-12. doi: 10.1111/dme.12329. [PubMed: 24117620].

74. Reilly NR, Lebwohl B, Mollazadegan K, Michaelsson K, Green PH, Ludvigsson JF. Celiac Disease Does Not Influence Fracture Risk in Young Patients with Type 1 Diabetes. J Pediatr. 2016;169:49-54. doi: 10.1016/j.jpeds.2015.10.032. [PubMed: 26589343]. [PubMed Central: PMC4729630].

75. Mackinder M, Allison G, Svolos V, Buchanan E, Johnston A, Cardigan $\mathrm{T}$, et al. Nutritional status, growth and disease management in children with single and dual diagnosis of type 1 diabetes mellitus and coeliac disease. BMC Gastroenterol. 2014;14:99. doi: 10.1186/1471-230X14-99. [PubMed: 24885742]. [PubMed Central: PMC4046848].

76. Leeds JS, Hopper AD, Hadjivassiliou M, Tesfaye S, Sanders DS. Potential coeliac disease in Type 1 diabetes mellitus: does a positive antibody lead to increased complications? Nutr Metab Cardiovasc Dis. 2014;24(4):378-83. doi: 10.1016/j.numecd.2013.09.005. [PubMed: 24393392]. 